\title{
Study on Implementation of Large Scientific Research in Military Academies
}

\author{
Lijin CAI \\ Training Staff Room \\ Acadamy of National Defense Information \\ Wuhan, China \\ syfclj2004xy@126.com
}

\begin{abstract}
Scientific research systems of some military academies are affected by the segmentation management system. The level of scientific research is low. The development strategy of large scientific research is put forward in order to change the current situation. The characteristics of the large scientific research are elaborated, the challenges facing large scientific research are analysed, and some suggestions on implementation of large scientific research are put forward in this paper.
\end{abstract}

Keywords-military academies; large scientific research; development strategy; suggestions

\section{INTRODUCTION}

At present, the scientific research systems of some military academies are affected by the segmentation management system, the scientific research team mainly consists of small number of staff in the department, the right talents don't be chosen in a wider range according to the research task. Due to the impact of the professional field, this small research team can not afford to difficult, large research projects, and which leads to the result that the research projects of the military academies are numerous, but the large-scale, high-level scientific research projects are very few. Experience has proved that the scientific research mode of small workshop is becoming more and more unsuitable for the needs of the construction and development of the military academy. In order to change this phenomenon, the existing pattern must be broken, scientific research talents must be chosen in the wider department, sense of joint research must be cultured, and the development strategy of large scientific research must be implemented.

\section{THE NATURE AND CHARACTERISTICS OF LARGE SCIENTIFIC RESEARCH}

\section{A. Nature of Large Scientific Research}

Large scientific research means that military academies should break through the restrictions of different departments and different subjects, integrate the scientific research talents in wider range, promote the cooperation among various departments, various subjects and specialties, the academies and other research institutes, the academies and enterprises, apply for and completes a number of key projects of national and military level through a wide range of cooperation, enhance the scientific research ability of academies, expand the impact of the military academies at home and abroad, promote leapfrog development of teaching, research, and personnel training of military academies.

\section{B. Characteristics of Large Scientific Research}

Large scientific research has three basic characteristics as follows: mutual cooperation, significant achievements, and expanded advantages.

The first characteristic is cooperation. It is necessary for large scientific research to eliminate the barriers between individuals, small groups of academies and advocate joint research, so cooperation is the most basic characteristic of large scientific research. Large scientific research emphasizes the role of the teams, requires people to abandon the thinking of small-scale research. All research resources should be shared, and be allocated rationally to the needs of the scientific research, flow with the major joint research programs. In addition to integrating internal resources, military academies should strengthen cooperation with other institutions, accomplish key projects of national and military level with them, which are difficult to complete on their own.

The second characteristic is significant achievements. The purpose of large scientific research is to comprehensively upgrade the scientific research level of military academies, make landmark research achievements continue to arise. It is difficult to enlarge and strengthen scientific research of military academies through low-level research. Large scientific research should combine military projects with civilian projects, mainly focused on the major research projects that are closely related to national defense building and preparations for military struggle. Achievements that are of great practical value are made through joint research. The level of scientific research of military academies is comprehensively upgraded, the scale of scientific research of military academies continues to expand, and the capacity of scientific research of military academies continues to increase.

The third characteristic is continually expanded advantages. To carry out research in the advantageous characteristic field is the way of large scientific research. At present, after the sixteenth military academy meeting, military academies are completing the transformation from academic education to professional education step by step. Each military academy has clear positioning, has formed their own unique advantages in areas of military personnel training. Every military academy should fully realize their own advantages, insist on independent innovation, continuously forge ahead in advantageous fields, make advantages and characters more obvious, establish the 
academy's own brand, and lay a solid foundation for the further development of the academy throughout the military circle.

\section{THE CHALLENGES FACING LARGE SCIENTIFIC RESEARCH}

The first challenge is the lack of important projects. Large scientific research needs important projects, the large scientific research is implemented on the premise of applying for important projects. Although some academies have a lot of research projects, these are small project and have no influence. There are three main problems about projects of some academies: firstly, from the view of the sources of projects, projects are mainly designated by superior management departments, major projects funded by Chinese Nature Science Foundation are rare, major scientific and technological projects of the state and the army are rarer. Secondly, from the view of the forms of study result, the forms of study result are mainly research reports, study results that are very valuable for military application are rare; thirdly, from the view of the amount of research funding, research funding of most of the research project is only thousands of dollars.

The second challenge is the lack of effective mechanism. Large scientific research means that different departments of the academy should join together to cooperate in joint research. Talents involved in the large scientific research come from different departments of the academy. The leaders of research teams must invest a lot of time and effort in organization and coordination. The main reason for this situation is the lack of organizational mechanisms. It is very difficult to require leaders of research teams to undertake everything that should be institutionalized. If leader of research teams is not a leader of the academy, or departments, he can hardly get talents come from different departments that he wants. Even if he could, how to deal with the relation between the research team with staff room deserves attention, so some experts are reluctant to engage in large scientific research.

The third challenge is the lack of evaluation system. Large scientific research needs huge work and long development cycle, but when the project is finished, the numbers of award-winning researchers are limited. Most of researchers involved in large scientific research have to face the embarrassing situation that they have worked hard for a few years with nothing. Young researchers that hope to get senior academic titles in the near future are reluctant to because of this. The main reason for this situation is the lack of scientific evaluation system. The scientific research workload cannot be assessed objectively and fairly. Instead, it takes only one year or two years to finish some small project, and which be used to apply for science and technology awards, so more people are willing to engage in small research projects[2].

\section{SOME SUGGESTIONS ON THE IMPLEMENTATION OF LARGE SCIENTIFIC RESEARCH}

\section{A. Applying Actively for Important Research Projects}

Research management department should adhere to preponderant subjects as a leader, and build several research teams that have dominant research areas of their own. According to the development plan of the country and the army and the actual situation of their own, research teams should conceive and look for important research projects around major theoretical problems and key technologies of the country and the military, and make a great effort to get projects. Applying for important research projects must have long term accumulation and key technologies. It requires academies to follow several major research directions, concentrate their resources, and study deeply with perseverance[3]. Researchers seize the opportunity to expand the application of research results, enlarge the influence of research results, and success will follow reputation.

\section{B. Establishing a Reasonable Flow Mechanism for Researchers}

Management departments should establish a reasonable flow mechanism for researchers, which make researchers flow according to scientific research project. Attention should be paid to the following two relationships[4]: one is the relationship between the flow and the immobilization. The core members of research teams remain relatively fixed. When undertaking specific research tasks, research teams diverted temporarily some people from various units according to the actual need of the project. Another is the relationship between research teams and related staff room, departments. Contribution of each unit to large scientific research is expressed in the form of money. Each unit should be compensated financially based on how many people take part in the project and how much they contribute. Only in this way are various units willing to take the initiative to let their teachers participate in large scientific research. So, teachers can do their research with one heart and one mind without the worries behind.

\section{Improving Performance Appraisal System}

The performance appraisal system underlined the assessment of the individual contribution to scientific research at present, and it is not conducive to building a high level scientific research team with a strong spirit of innovation. Reasonable performance appraisal system must be established. The index system of performance appraisal system should stress the following two aspects[5]: Firstly, performance appraisal system should stress the team rather the individual. Secondly, it should stress the process, instead of simply stressing the result. Performance appraisal system should raise the impact of performance of scientific research team on the individual performance, reflect fully the workload of each researcher who engages in large scientific research but his name is not on the list of award winners 


\section{Strengthening Research Environment Construction}

The more high-end scientific research, the higher the requirement of research conditions and means will be. Conversely, research conditions and means are also increasingly become important threshold of research, it is very difficult to apply for large projects without better research conditions. The country and the military certainly support scientific research teams of national key laboratories which make great achievements. At present, the main problem in laboratories of military academies is that key laboratories of partial military academies are few in number, characteristics of laboratories are not distinctive, resources of laboratories are not rich. It is difficult to meet the need of large scientific research. So, on the one hand, military academies should upgrade the experimental platform through methods like purchasing equipments, beautifying the environment, or integrating resources [6]. On the other hand, military academies should concentrate the limited funds to construct some first-class laboratories which are of distinctive characteristics according to needs of the research.

\section{E. Strengthening Talent Teams Construction}

It is difficult for individual to make great achievements even if he has very strong research ability. So, talented teams construction is particularly important to the implementation of large scientific research. Large scientific research needs a number of academic leaders who are upright style, rigorous scholarship, and good at communicating, better organization and coordination capability[7]. Under the leadership of academic leader, researchers who come from different departments can hold together to form a research team with a strong spirit of innovation and teamwork. Academic leaders should really play the leadership role in leading the research team to achieve the objectives through their academic achievements, diligent work style and force of personality. They must develop academic democracy, provide the opportunities for other's progress, and help their team undertake large projects and make great achievement, study at the forefront of scientific research all the time.

\section{F. Establishing the Academy's Own Brand}

The implementation of large scientific research strongly encourages research teams to make them stronger in a given field, and develop their own characteristics. Each academy has very limited faculty and research resources, has its advantages and disadvantages. When implementing scientific research, the relations between characteristics and comprehensiveness should be properly handled. It is wrong to make one-sided pursuit of new research content. It is important for research to begin with the characteristics and advantages of the academy[8]. Academies must invest limited resources in advantageous research field, explored them in depth, make advantages and characters more obvious, continuously expand the impact of academies at home and abroad, promote leapfrog development of teaching, research, and personnel training of academies.

\section{REFERENCES.}

[1] Zhao YueHua, "A Comparative Study on Science \& Research institutions in Chinese colleges and Universities," Scientific Management Research, vol. 28, pp. 30-33, Feb. 2010.

[2] NIU Hongtai, "Problems in Scientific Research in China's Colleges and Universities:A Study from the Perspective of Nobel Prize Complex,” Journal of Higher Education Management, vol. 3, pp. 1927, July 2009.

[3] HE Yu-yan, "Project Application and Self-management,” Technology and Innovation Management, vol. 33, pp. 262-264, May 2012.

[4] Lin Jizhi; Zhang Xiangqian, "Theoretical Analysis on Evaluating System of Teaching and Research-typed Universities," Science \& Technology Progress and Policy, vol. 27, pp. 136-140, Sep. 2010.

[5] Liu Huiqun, "Study on Performance Appraisal Mechanism of Scientific Research Team in Universties," Science \& Technology Progress and Policy, vol. 27, pp. 138-142, Dec. 2010.

[6] MENG Qingjin; QIU Cheng-li; YANG De-li, "Scientific Research Personnel to Improve Environmental Promote Researching," Scientific Management Research, vol. 28, pp. 84-88, Oct. 2010.

[7] TANG Hongqin; ZHAO Jin-qin; ZHANG Xiao-lan, “On the Innovation of Scientific Research Management in Universities under the new Situation,” Technology and Innovation Management, vol. 31, pp. 150-153, Mar. 2010.

[8] Liu Chun, "Ways of fostering scientific research features of appliedtyped undergraduate institutions," Journal of Fujian University of Technology, vol. 9, pp. 498-500, Oct. 2011. 